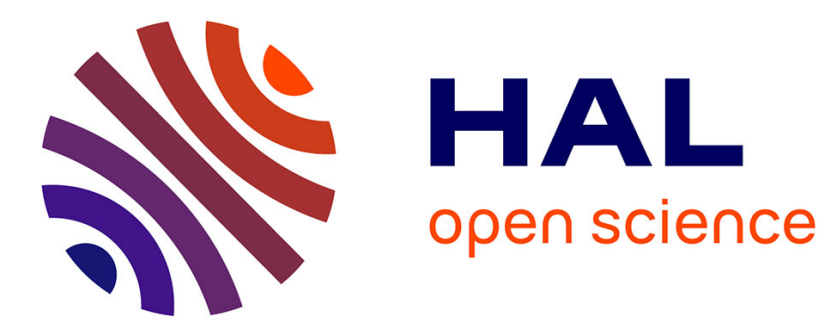

\title{
Carbon economy of a young walnut tree
}

André Lacointe, François Alain Daudet, Pascale Maillard, Philippe Archer

\section{To cite this version:}

André Lacointe, François Alain Daudet, Pascale Maillard, Philippe Archer. Carbon economy of a young walnut tree. First International Symposium on Walnut Production, Sep 1989, Budapest, Hungary. hal-02930432

\section{HAL Id: hal-02930432 \\ https://hal.inrae.fr/hal-02930432}

Submitted on 4 Sep 2020

HAL is a multi-disciplinary open access archive for the deposit and dissemination of scientific research documents, whether they are published or not. The documents may come from teaching and research institutions in France or abroad, or from public or private research centers.
L'archive ouverte pluridisciplinaire HAL, est destinée au dépôt et à la diffusion de documents scientifiques de niveau recherche, publiés ou non, émanant des établissements d'enseignement et de recherche français ou étrangers, des laboratoires publics ou privés. 
Number 284

October 1990
Technical Communications of ISHS

International Society for Horticultural Science

\section{First International Symposium on Walnut Production}

Editor

P. Szentiványi

Budapest, Hungary

25-29 September 1989 


\section{CQARBON ECONOMY OF A YOUNG WALNUT TREE}

A.Kajil, A.Lacointe, F.A.Daudet, P.Mallard \& P.Archer

I.N.R.A., Laboratoire de Blocllmatologie

Domaine de Crouelie

F-63039 Clermont-Ferrand Cedex

France

\section{Abstract}

The carbon economy of young wafnut grafted trees In their second growing year, was Investigated through carbohydrate analysis and 14C labelling experiments.

in October, 3 weeks before leaf-fall, starch and soluble sugars represented up to 25\% of the total dry matter, with starch highly predominant among them. Sucrose was more abundant in the bark than in the wood, while the starch content was similar in both compartments. The reserves were located in the wood and in the innermost pith.

Between October and January, the minor roots $(\phi<15 \mathrm{~mm})$ underwent a significant depletion of their August-labelled reserves, whereas the tap-root was the main organ depleted between January and May (early growti resumption).

Both iabelilng experiments, and root resoiration menitoring, provided some information about the timing of transiocation processes and the ear!y metabolism of the transiocation compounds.

\section{Introduction}

Modelling of growth and carbon movements in trees currently available - most of them for apple - are generally valld only for short periods characterized by constant growth patterns (Frossard \& Laccirte, 1988). In order to build models valld for a long period - 1 year or mare -, an improvement of the understanding and quantitation of the carbon balance in the annual cycle is needed. To this end, the first results of a current program on young walnut trees. carried out in Clermont-ferrand were presented here. Particulariy, the formation of reserves and their subsequent utlization, both in winter during the so-called 'rest-perlod', and in spring at growth resumption, were investigated.

\section{Material and metrods}

Wannt (Juglans regia L.) cV. Lara scions were pianted in late april 1989 (or 1989 for the respiration experiment), in 200 ilter containers.

The culture was carried out in natural conditions with irrigation.

The cartoon reserves and their dynamics were investlgated through : * carbohydrate analysis in mld-Octoder.

* :4C movements after labelling in August, as deriveo from 3 harvests:

* mid-October (Autumn): shoot growth over

* mid-January (Winter): rest-period

* mid-May (Spring) (2 fuli-grown new leaves per shoot)

Auta Horticulturae 284, 1990

Walmut Production 


\subsection{Carbohydrate analysis}

This part concern only the Autumn harvest. Dlfferent carbohydrates (fructose, sucrose, glucose and starch) were extrected in methanal/chloroform/water $12 / 5 / 3$ and assayed by enzymatic and spectrometric methods.

\subsection{C-experiments}

In mid-August, each tree was fed with $2 \mathrm{mCl}(74 \mathrm{Mga}) 14 \mathrm{CO}_{2}$, with an indivldual chamber used elther as $14 \mathrm{C}$ lebeiling, or as a gaz exchange monitorlng system allowing Independent measurement for shoots and roots.

For each harvest, 2 trees were sampled and divided In 14 organs (Fig 1) whlch were freeze-dried and ground.

The radlcactivity of each organ was measured after harvest with an argon-methane flow counter.

Autoradiographs were also performed for the localization of ${ }^{14} \mathrm{C}$ within organs.

The evolution of ${ }^{14} \mathrm{CO}_{2}$ from root respiration was monltored contlnuously for 15 days after labolling (FIg 2).

* the total $\mathrm{CO}_{2}$ evolution was assessed with a gas-exchange masurement system including an IR gas-analyser.

* the soecifle radioactlvity of the $\mathrm{CO}_{2}$ was assessed by titrimetry and llauid scintillation after trapoing In $\mathrm{NaOH}$.

\section{Results and discusston}

\subsection{Fate of carbon assimiliated in August:}

As derived from root respiration monltoring due to the duration of the translocation processes, the ${ }^{14} \mathrm{CO}_{2}$ speclfic radioactivity (SR) reached a maximum 1 day after labelling.

After 6 days, the export was over, the labelled compounds were incorporated in metabollc pools with long time constants : the SR had decreased to a much lower value, still decreasing very slowly.

\subsection{Blochemistry, locatlon and amount of carbohydrate reserves in}

\section{Qctober}

Only starch and soluble sugars were investlgated, but they reoresented up to $25 \%$ of the total dry matter weight (F/g. 3 ) : they were certainly the main class of reserve substances. Among them, starch was predominant In all perennial organs. Generally, there was only little difference In the concentrations of starch between wood and bark. Sucrose. the main translocation form of assimliates, was more concentrated in the bark than in the wood. However, there was some sucrose In the wood. Thls most probably reflected the lateral transport of sucrase in the rays towards the reserve storage areas, where th would be converted into starch.

The reserves were mostly located in the lower part of the olant, including the root-stock part of the stem, Even the smallest roots contsined a signifleant fraction of the total reserves ( Bachelard \& Wightman 1973, in Jourdan, 1980). 
As for the location of reserves within the organs, the wood formed from current assimllates was intensely labelled (periphery). Labelled reserves were localized in the rays and in the central pith (Fig4): even the oldest tissues took part in reserve storage. Simllar results were obtained by Glerum, (1980) and Kandlah, (1979) on apple trees.

\section{3. carbon movements from October to May}

The total radloactivity of the perennial parts decreased between October and January (Fig 5 ), due mainly to the maintenance respiratory losses : the plant was not totally "Inactive" during the so-called "restperiod". These losses concerned malniy, if not only, the minor roots of all sizes $(\varnothing<15 \mathrm{~mm}$ ). The leaves remained the most radioactive organs per mass unit untll leaf-fall (Lacointe, 1988) on walnut.

Between January and May, the decrease went on in the smallest roots $(\phi<3 \mathrm{~mm})$; whereas an Increase was noticed in the medium roots $(\phi 3-7 \mathrm{~mm}$ ). This could be due to a redistribution of nutrients from the former to the latter, as mentloned In literature (Prlestley, 1981) concerning stone-fruit trees.

A decrease was also observed in the twigs, both upper and lower, which were the most labelled organs per mass unit together with the smallest roots.

However, the organ which was most depleted of its reserves at growth resumption was the tap-root (Hansen, 1967) on apple.

\section{References}

FROSSARD,J.S, \& LACOINTE,A. -1988. Les Varlatlons saisonnières de l'utilisaticn du carbone chez les arbres au stade végétatif, en zone tempérée (revue biblicgraphique). Bull. Soc. Fr., 135, Actual. bot., 1988 (1), 9-24.

GLERUM C. -1980 . Food sinks and food reserves of trees in temperate climates. N. Z. J. for, Sci,, 10, (1), 17B-185,

HANSEN P. $-1967,14 \mathrm{C}$-studies on apple trees. 3. The Influence of season on storage and mobilization of labelled compounds. Physiol. Plant, 20, 1103-1111

JOURDAN J. -1980. Variations sajsonnières de la morphogénèse et de la croissance des systemes aériens et souterralns chez le peuplier. Leurs relations avec les glucides et les transferts minéraux. USM Grenoble, Thèse (Or. es Sci.). Faculté des sciences, Grenoble, (FRA), $160 \mathrm{p}$.

KANDIAH S. -1979 . Turnover of carbohydrates in relation to growth in apple trees. II Distribution of $14 \mathrm{C}$ assimilates labelled in Autumn, Spring and Summer. Ann. Bot., 44, 185-195.

LACOINTE A. -1988. Assimilate allocation and carbon reserves in juglans regia L. seedling. Communication. Symposium international sur la physiologie de l'arbre, INRA/IUfRO, Nancy (FRA), i988/09/25-30. INRA, Nancy, (FRA), 3p.

PRIESTLEY C.A. - 1981. Perennation in woody frult plants and its relationship to carbohydrate turnover. Ann. appl. Blol., 98, 548-552. 


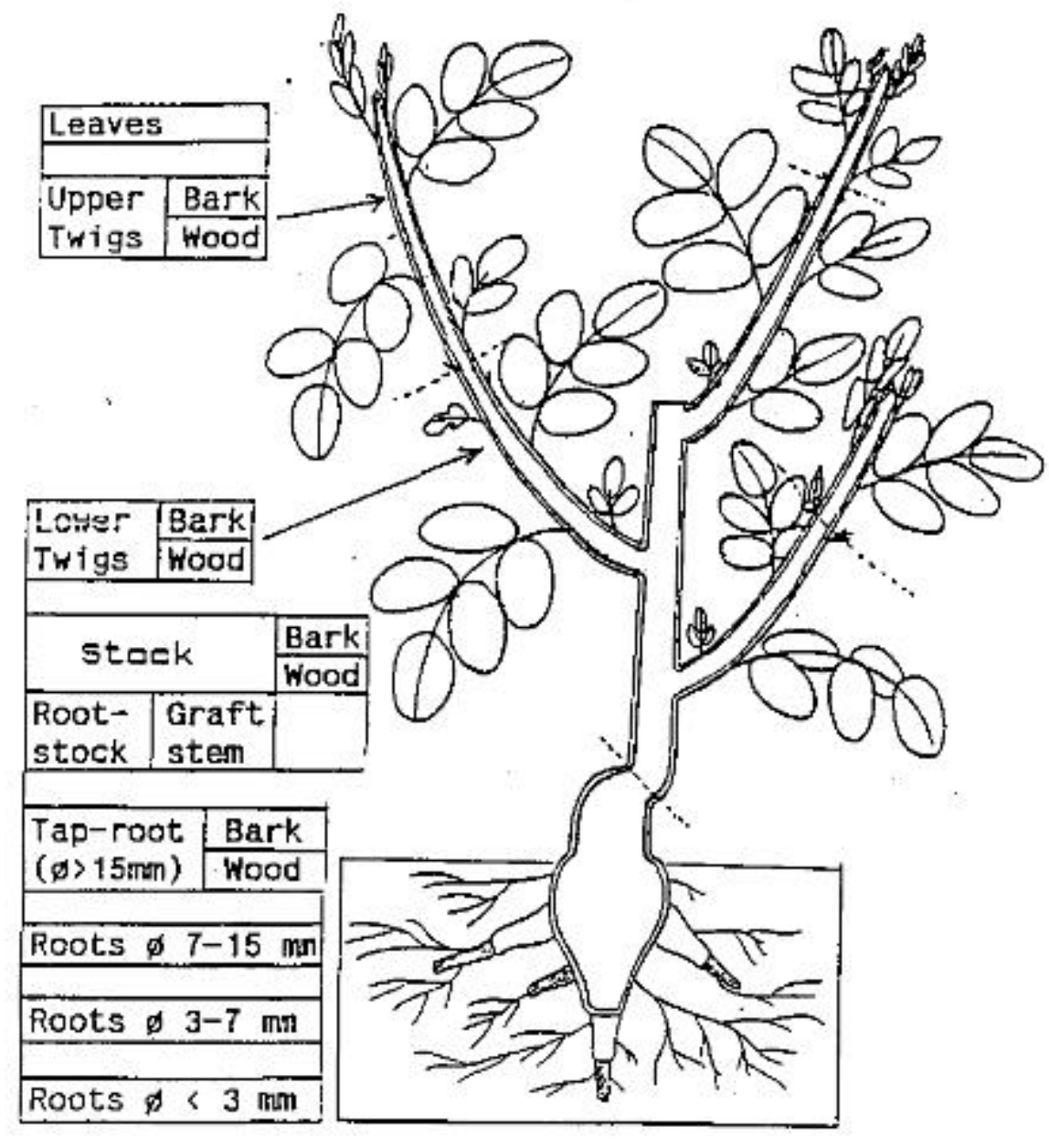

Fig. 1 -Schematic representation of a young walnut grafted tree, showing the different parts analysed for radicactivity and carbohydrates conterit. 


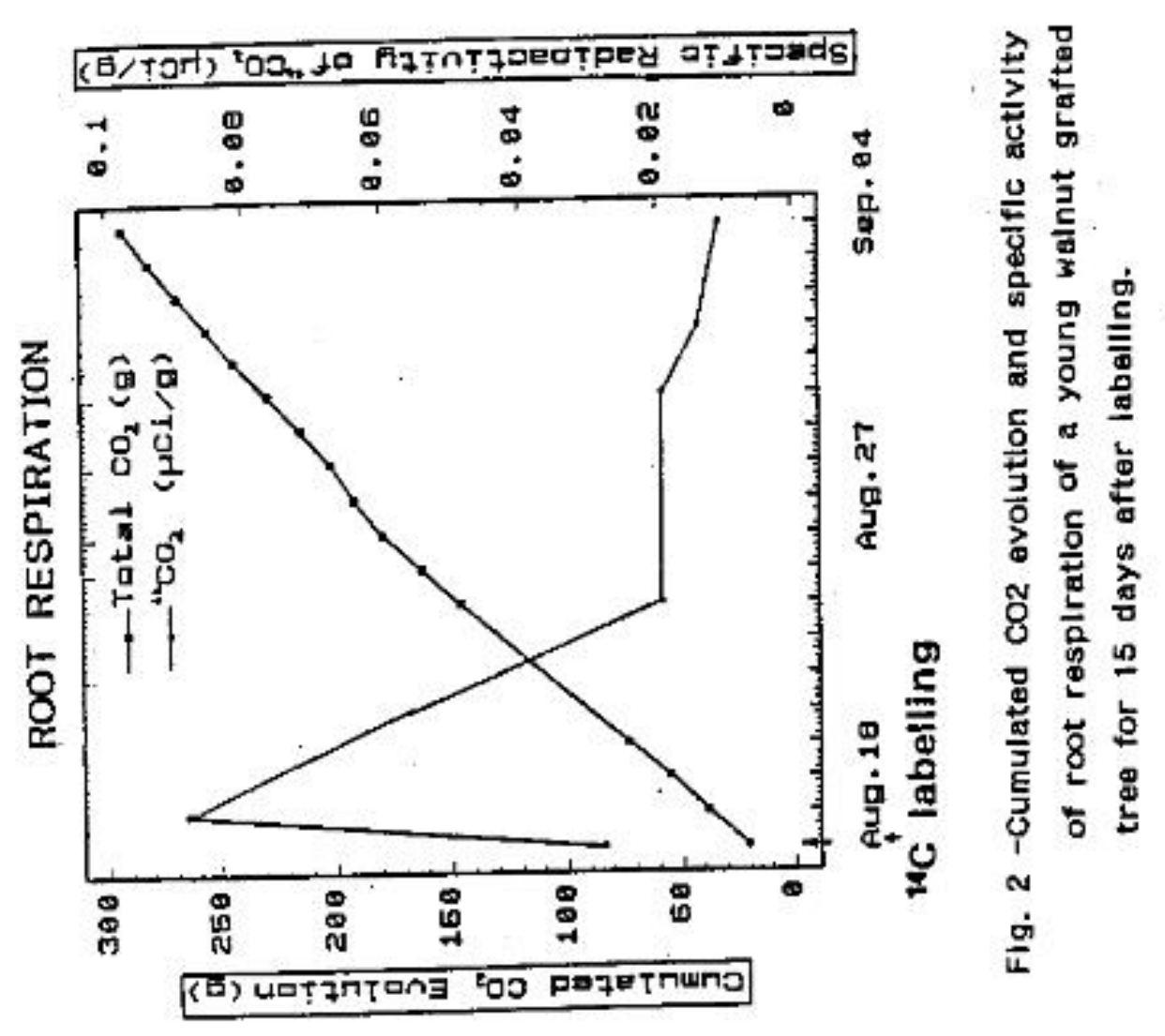




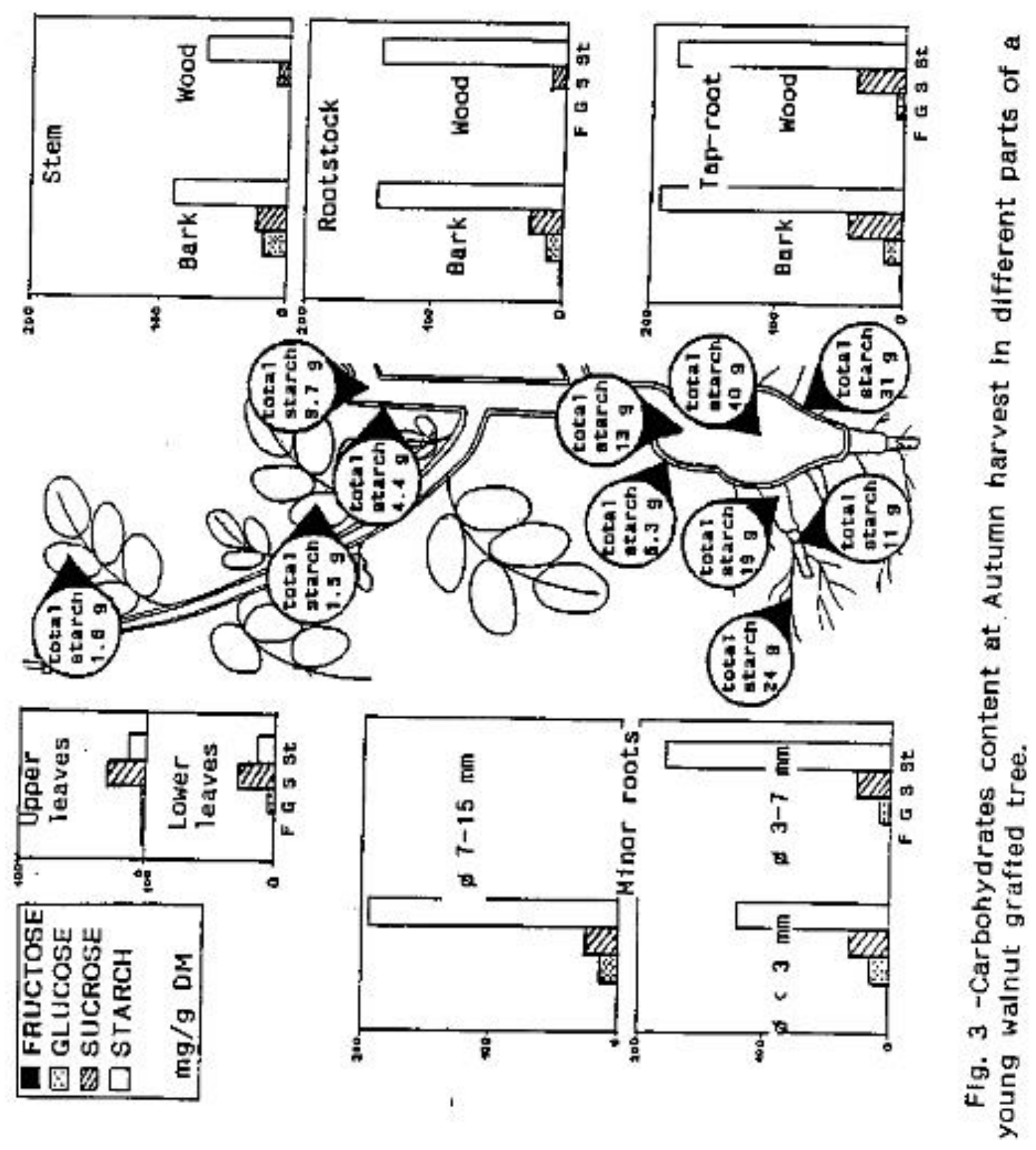


Total Radidactivity ( $\mu \mathrm{Ci})$

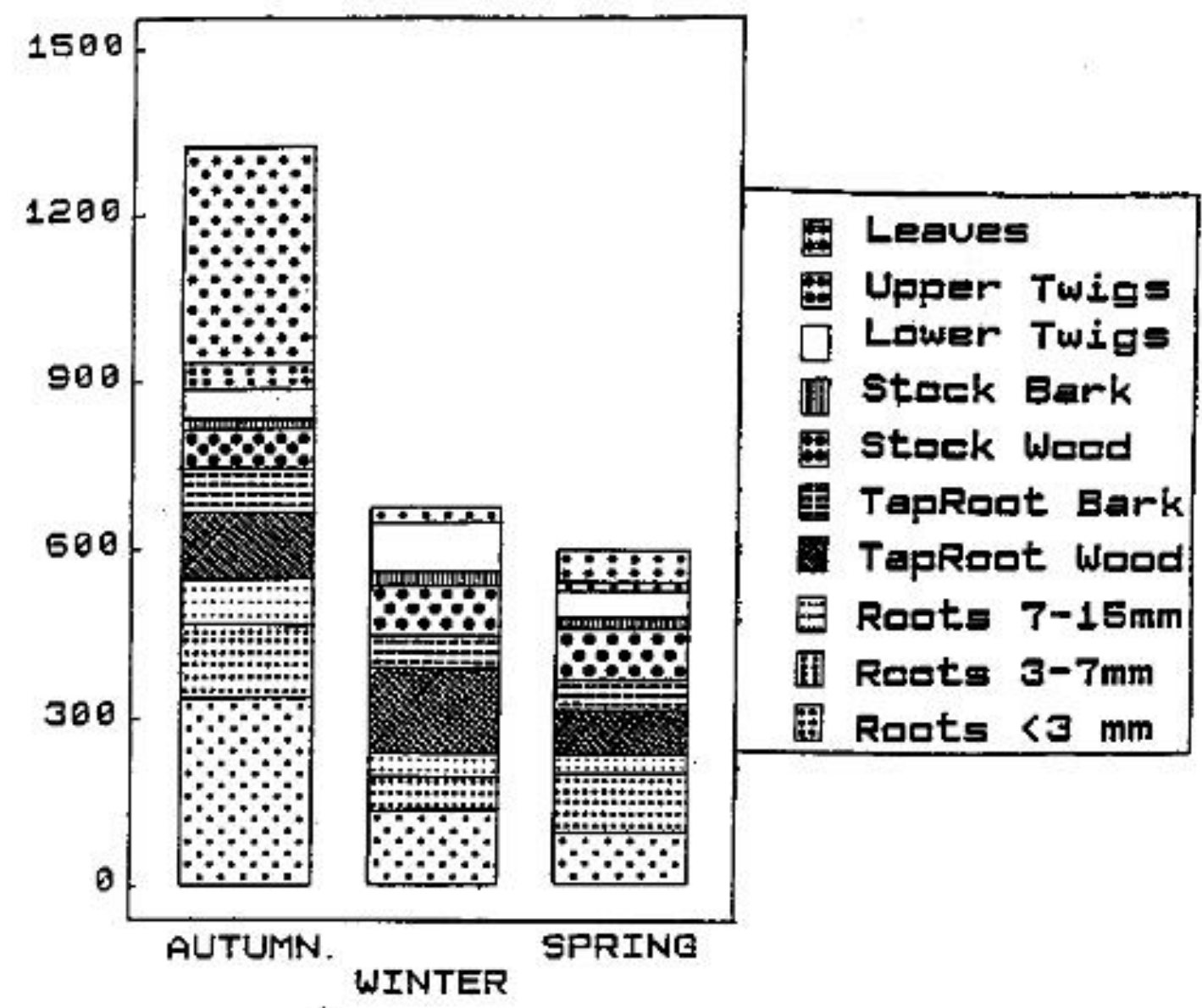

Fig. 3 -Carbohydrates content at Autumn harvest in different parts of young walnut grafted tree. 

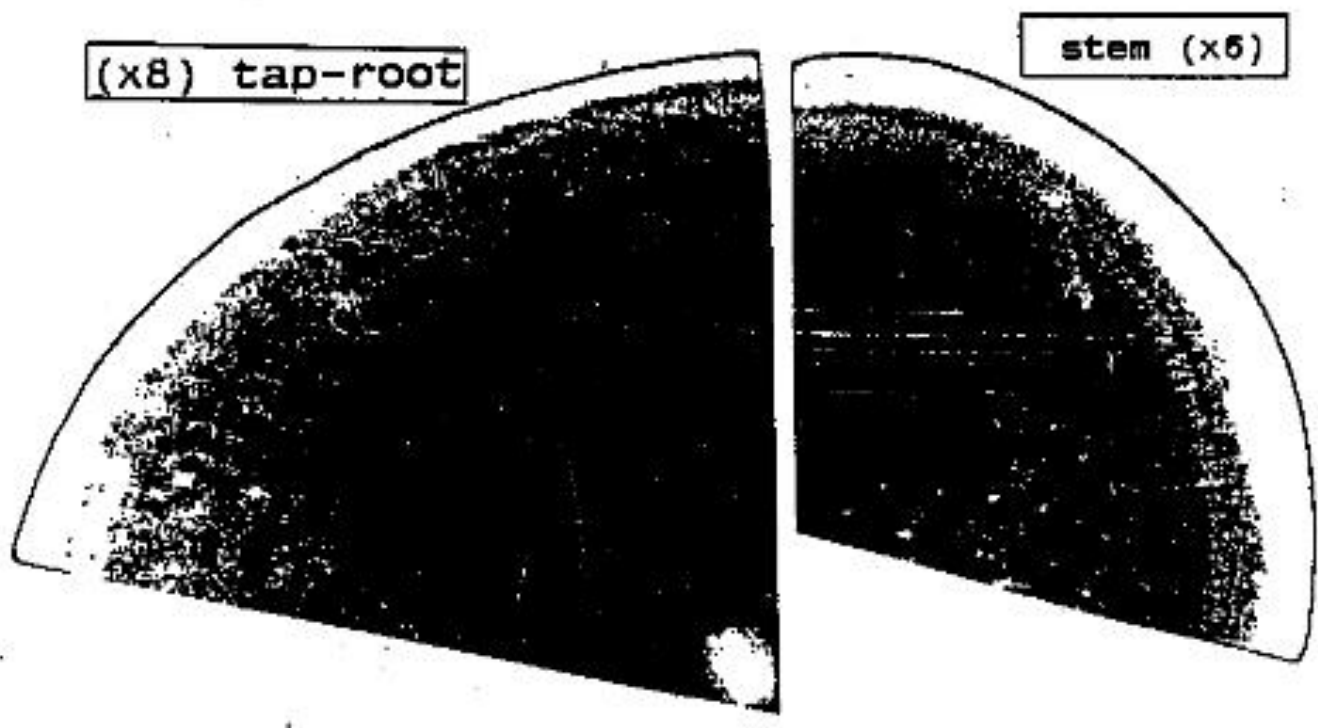

Autoradiographs of wood cross-sections

(Autumn Harvest)

Flg. 4-Autoradiographs of the tap-root and the stem of a young walnut grafted tree, showing tissular repartition of reserves. 
Total Radioactivity ( $\mu \mathrm{C} i)$

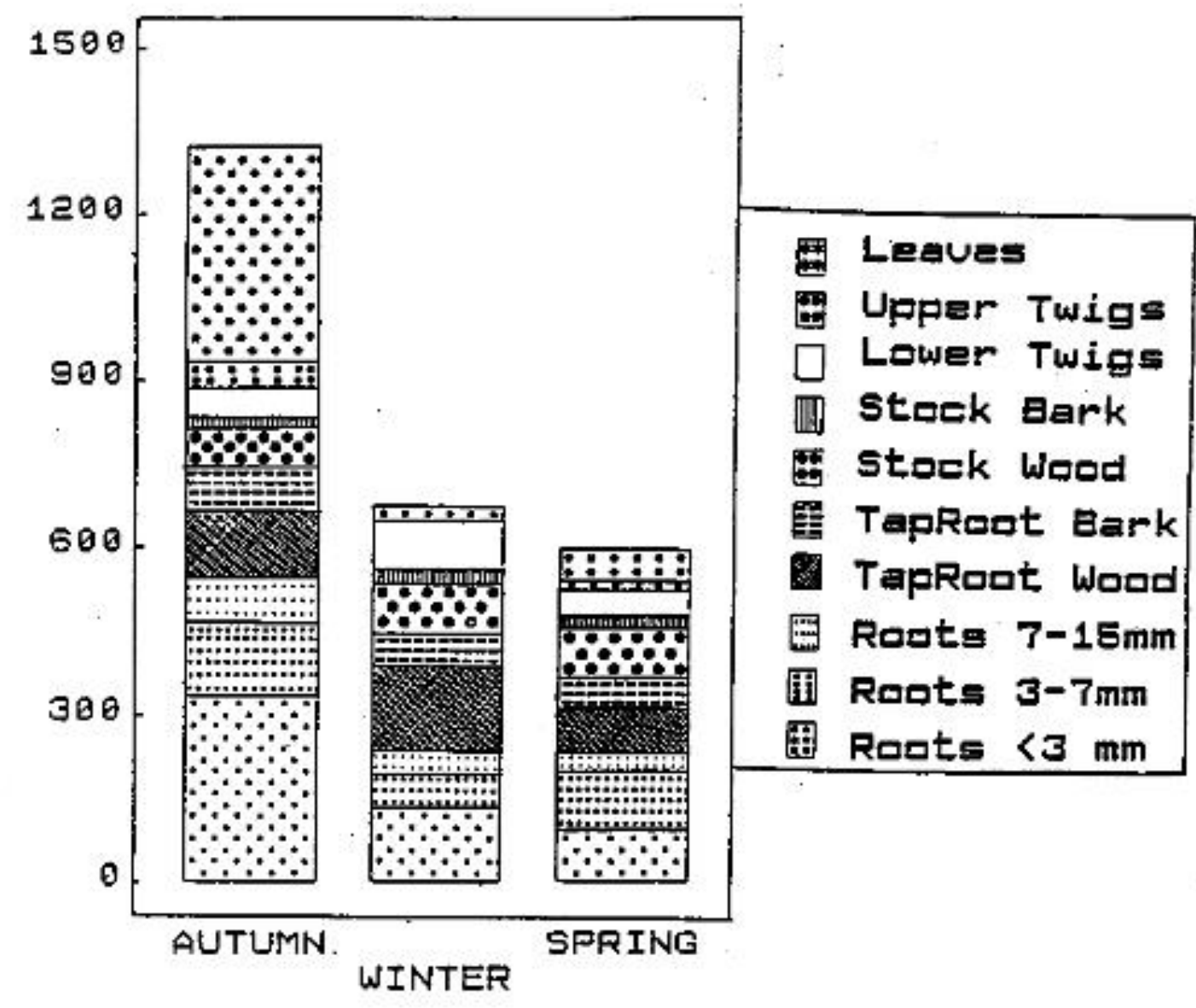

Fig. 5-Seasonal variations of the total radioactivity in the different parts of a young walnut grafted tree. 


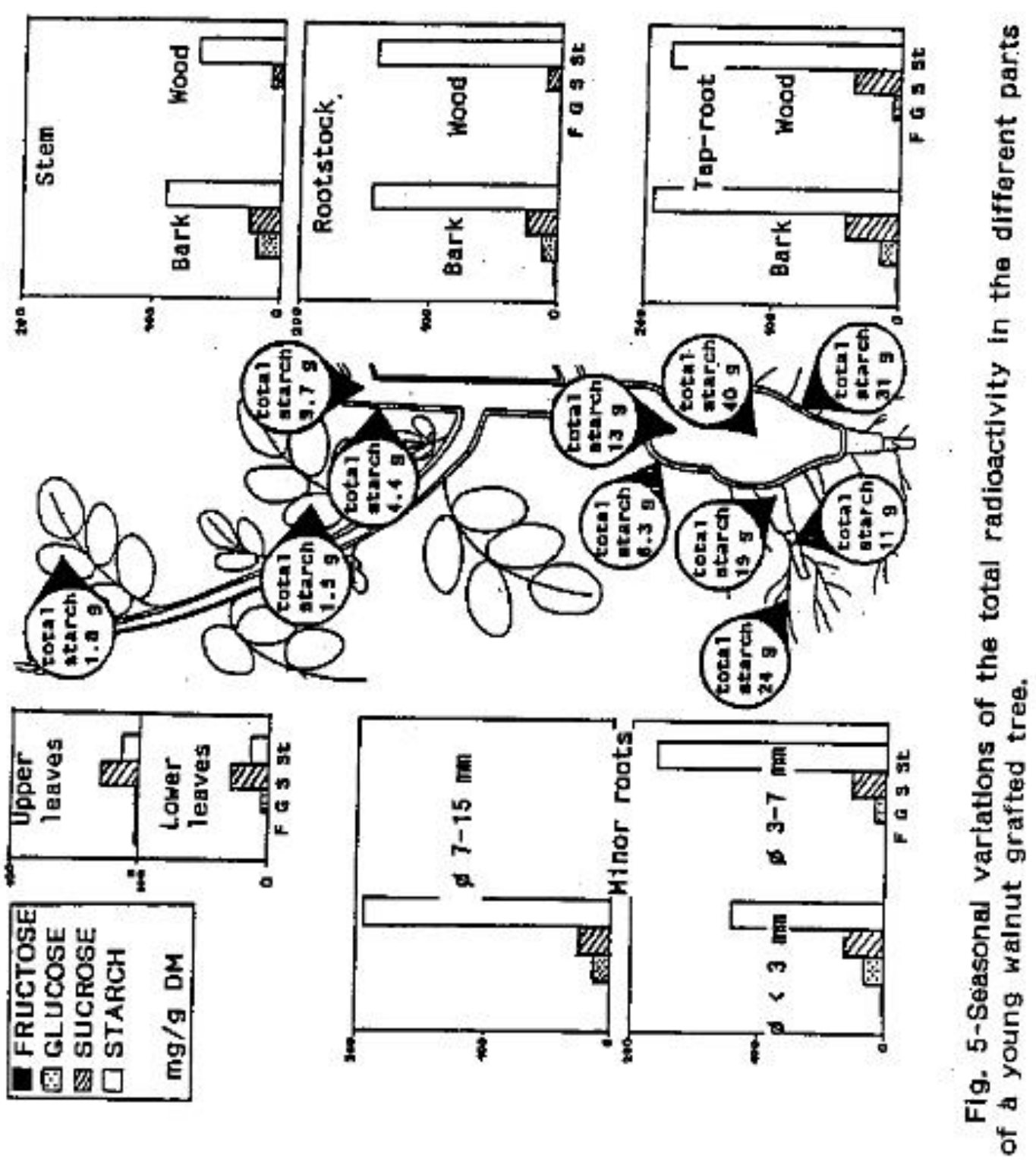

